\title{
POLITIKK
}

SKANDINAVISK TIDSSKRIFT

FOR INTERNASJONALE STUDIER

Årgang 75, Nummer 2, side 180-202, 2017, ISSN 1891-5580, www.tidsskriftet-ip.no, Publisert desember 2017

\section{Nato og amerikanske kjernevåpen i Europa: Hvordan forklare status quo?}

\section{Vinnerartikkel Ordingprisen 2016}

\author{
Maïka Skjønsberg \\ Associate Researcher at GRIP (Group for Research and Information on Peace and \\ Security) and Visiting Researcher at Université Libre de Bruxelles.
}

\begin{abstract}
Sammendrag
Det totale antall amerikanske kjernevåpen i Europa har minket med 97 prosent siden toppen i 1970-årene. På tross av en serie politiske initiativer for å trekke ut de resterende stridshodene, finnes det omkring 180 amerikanske B-61-bomber på europeisk jord: i Belgia, Tyskland, Nederland, Italia og Tyrkia. Et kvart århundre etter avslutningen på den kalde krigen synes ikke de taktiske kortdistansevåpnene å tjene noen militær hensikt. NATOs kjernefysiske kapasitet ville ikke forringes om disse kortdistansevåpnene ble fjernet fra europeisk territorium. Denne artikkelen tar derfor sikte på å forklare hvorfor disse kjernevåpnene fremdeles er på europeisk jord.

Artikkelen identifiserer et sett av aktører, som ved å fremme et narrativ om NATO som en kjernevåpenallianse basert på byrdefordeling og transatlantisk solidaritet, sørger for at de amerikanske kjernevåpnene forblir i Europa.
\end{abstract}

Nøkkelord: NATO • kjernevåpen • byrdefordeling • transatlantisk solidaritet • militær-industrielle kompleks • B-61 • F-35

I 1953, da den kalde krigen ble intensivert, utplasserte USA kjernevåpen i Europa. Behovet for å stasjonere atomvåpen i Europa var motivert av oppfatningen om at Sovjetunionen og deres allierte i Warszawapakten hadde et overtak både når det gjaldt konvensjonelle kapabiliteter og - etter suksessen med Sputnik-raketten i 1957 - langtrekkende missilteknologi (Warner 1989). Mens førstnevnte ble oppfattet som en alvorlig trussel mot Vest-Europa - et forsøk på landinvasjon var sett på som en reell mulighet - var det siste ansett som en trussel mot USA ved et (mulig) kjernefysisk 
angrep. I denne konteksten var utplassering av taktiske kjernefysiske våpen ${ }^{1}$ i Europa et virkemiddel for å styrke NATOs avskrekkingskapasitet.

Antallet amerikanske kjernevåpen utplassert i Europa var på sitt høyeste i 1970-årene, da europeiske stater var vertskap for om lag 7300 amerikanske stridshoder av 24 ulike typer (Gregory 1976: 76). Som følge av den antatt minskede trusselen fra Sovjetunionen (og senere Russland), ble våpnene deretter gradvis redusert. I kvantitative termer er i dag bare tre prosent av de utplasserte stridshodene fremdeles på europeisk jord (Department of Defence 2008: 59). De om lag 180 gjenværende våpnene er alle gravitasjonsbomber av typen B-61, som leveres med taktiske fly.

NATOs offisielle politikk er å verken bekrefte eller avkrefte tilstedeværelsen og lokasjonen til bombene. Ekspertene mener imidlertid at de nukleære stridshodene er lagret på seks flybaser i fem europeiske land: Büchel-basen iTyskland, Kleine Brogelbasen i Belgia, Volkel-basen i Nederland, Incerlik-basen i Tyrkia, samt Aviano- og Ghedi Torre-flybasene i Italia (Norris og Kristensen 2011: 65).

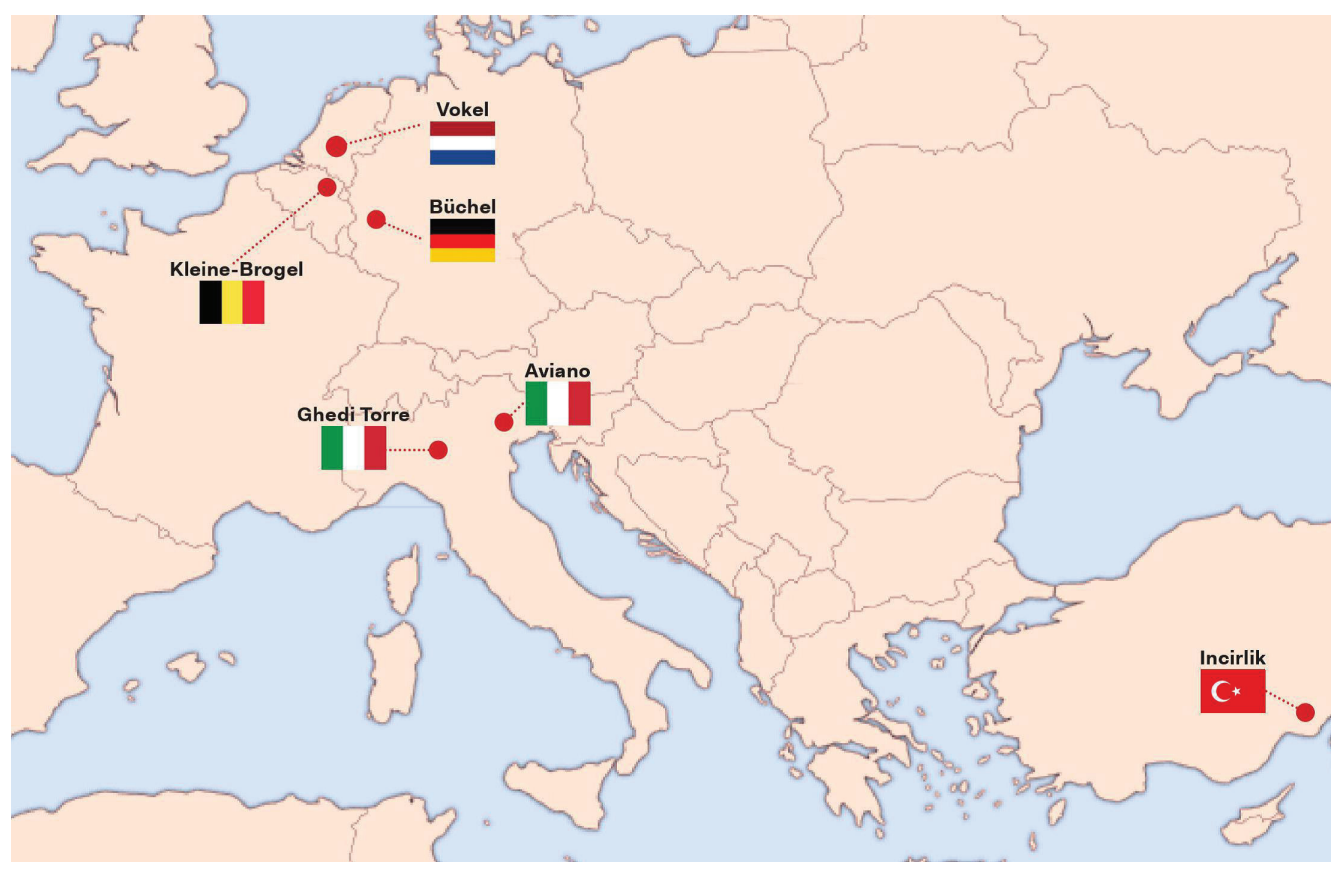

Figur 1. Plassering av B-61-bomber i Europa

Kilde: GRIP

\footnotetext{
${ }^{1}$ Taktiske kjernevåpen har kort til medium rekkevidde og er ment til bruk på slagmarken ved en mulig invasjon. Bombene som er utplassert i Europa kan bli fraktet med taktiske fly som har maksimal rekkevidde på $1350 \mathrm{~km}$. De skiller seg dermed fra strategiske kjernevåpen, som har langt større rekkevidde, og som er tiltenkt strategisk bombing av store byer.
} 
I militære termer har de gienværende B-61-bombene begrenset verdi. Dette er blant annet påpekt av aktører som det amerikanske forsvarsdepartementet. I kontrast til situasjonen ved begynnelsen av den kalde krigen, har NATO i dag overveldende internasjonal overlegenhet hva angår konvensjonelle militære kapabiliteter. I tillegg har USA nå missilteknologi som muliggiør angrep med strategiske kjernevåpen hvor som helst i verden på kort tid - trolig kortere enn det ville ta å utløse et taktisk kjernevåpen (Pomper, Potter og Sokov 2010: 81).

Det er ikke konsensus innen NATO om amerikanske atomvåpen i Europa. Faktum er at utplasseringen var kontroversiell helt fra starten. NATO-land som Danmark og Norge nektet å være vertskap for kjernevåpen i fredstid så tidlig som 1950-årene (Lie 2014). Siden slutten på den kalde krigen har det vært flere forsøk på å få stridshodene ut av Europa, eller i det minste å starte en åpen og transparent dialog innenfor NATO-rammen. Ingen av delene har lyktes.

Bevaringen av bombene i disse fem europeiske landene kan ikke forklares kun ut ifra NATOs sikkerhetsbehov. Våpnene har en svak militær verdi og er ikke rettet mot noen konkret trussel. Flyene som er utstyrt for å transportere bombene, er på et lavt beredskapsnivå (NATO Parliamentary Assembly Report 2010), og NATO har for lengst eliminert beredskapsplanene for målretting av våpnene. Utplasseringen medfører for øvrig betydelige kostnader for vertslandene. Hvordan kan man så forklare B-61-bombenes fortsatte tilstedeværelse? Formålet med denne studien er å forstå hvorfor dette er tilfelle, gitt våpnenes begrensede militære nytte og høye økonomiske og politiske kostnader.

Professor Nick Ritchie (2010: 466) argumenterer for at nasjonal (u)sikkerhet ikke er nok til å forklare hvorfor noen land beslutter å beholde kjernevåpen:

There are wider obstacles to relinquishing nuclear weapons that must be examined in order to understand why states retain nuclear weapons and will find it difficult to abandon them, even if the strategic security threats that motivated their original acquisition have diminished or faded altogether.

Nedrustning kan ikke utelukkende forstås som en rasjonell analyse av kostnad og nytte; det må analyseres gjennom en bredere, sosiologisk tilnærming. Som Ritchie påpeker, er ikke kjernevåpen kun et politisk-militært redskap for avskrekking, men også sosiale objekter innebygd i et nettverk av sosiale relasjoner, interesser og identiteter (Ritchie 2010: 466). B-61s tilstedeværelse i Europa fremstår som et symbol på byrdefordeling og det transatlantiske bånd, to av de viktigste pilarene i NATO. Selv om bevaring av B-61 ikke nødvendigvis tjener NATOs samlede- eller vertslandenes individuelle interesser, tjener det interessene til andre innflytelsesrike aktører. Laboratoriene som fremstiller våpnene og selskapene som utvikler leveringsmekanismene for bombene, som F-35 kampfly, er eksempler på slike aktører.

De følgende avsnitt tar for seg interne prosesser i NATO, interessene til kjernevåpenmaktene USA, Storbritannia og Frankrike, samt interessene til vertslandene Tyskland, Nederland og Belgia. De tre sistnevnte land er uten tvil de 
vertslandene som har gått lengst i argumentasjonen om å trekke ut våpnene. Et underliggende spørsmål er hvorfor disse landene likevel godtar å beholde kjernevåpen på sitt territorium.

\section{Initiativ for å utfordre status quo}

I februar 2010 sendte utenriksministrene fra Belgia, Luxembourg, Nederland, Norge og Tyskland et brev til daværende generalsekretær i NATO, Anders Fogh Rasmussen, der de ba ham inkludere et dagsordenpunkt med ordlyden "NATO's nuclear policy in our evolving security environment» til NATO-møtet i Tallin senere samme år (Letter to Secretary General 2010). Avsenderne ville sette spørsmålet om taktiske kjernevåpen på NATOs dagsorden - og foreslo å diskutere spørsmålet i NATOs viktigste beslutningsorgan, The North Atlantic Council. Dette forslaget ble ikke godt mottatt av alle. Ifølge en tidligere diplomat i USAs delegasjon til NATO, som ble intervjuet i forbindelse med denne studien, ble initiativet for å diskutere B-61 motarbeidet av Frankrike.

Well, it got subverted. Plain and simple. It got defunct by the French. They turned it into a sort of generic discussion of arms control and you know blabla these are strategic priorities. It was supposed to be a strategic nuclear posture review and then it got turned into a defence posture review because the French would not allow the use of the word "nuclear". And in a defence posture review, you can put anything. [...] What happened was that the French refused to join consensus on a real change to nuclear policy and nuclear posture, they just said no. ${ }^{2}$

Diskusjonen på NATOs toppmøte i Lisboa senere i 2010 førte heller ikke til noen omfattende debatt rundt kjernevåpen. Da Frankrike motsatte seg et «nuclear review», foreslo Tyskland et «Defence and Deterrence Posture Review» (Seay 2013). Tysklands målsetting var å redusere kjernevåpnenes rolle i NATOs strategi, men dette var ingen suksess. Den tidligere amerikanske diplomaten beskrev tyskernes nederlag slik:

Germany is gnashing their teeth at this point, they are pulling their hair out, they have been rolled again, they have been lied to by the French that there is going to be a meaningful discussion, there is never a meaningful discussing at NATO about these issues. ${ }^{3}$

Som et neste steg ble det etablert en komité for å se på betraktninger angående reduksjon av kjernevåpen (the Special Advisory and Consultative Arms Control, Disarmament and Non-Proliferation Committee). Formålet med denne komiteen er å øke transparensen og tilliten mellom NATO og Russland. Ifølge den tidligere amerikanske diplomaten har imidlertid ikke denne komiteen autoritet til å endre NATOs kjernevåpenpolitikk: «all it can do is talk».

\footnotetext{
${ }^{2}$ Intervju med tidligere amerikansk diplomat ved USAs delegasjon til NATO, 16.3.2015.

${ }^{3}$ Intervju med tidligere amerikansk diplomat ved USAs delegasjon til NATO, 16.3.2015.
} 
Etter flere debatter uten suksess gikk landene som ønsket uttrekking av amerikanske kjernevåpen, inn for en trinnvis tilnærming. Første steg var å be om økt transparens. Et eksempel på dette var det «non-paper» som Polen, Nederland, Norge og Tyskland fremla på NATOs utenriksministermøte i Berlin i april 2011. I dette forslaget ba man om økt transparens og tillitsbyggende tiltak for taktiske kjernevåpen i Europa. Dokumentet vektla imidlertid også at reduksjonene ikke bør forfølges ensidig eller svekke den transatlantiske koblingen, at en slik prosess bør baseres på prinsippet om udelelig sikkerhet innad i forsvarsalliansen, og gjenspeile gjensidighet mellom NATO og Russland (NATO non-paper 2011). Dette understreker noen av de forholdene som gjør spørsmålet om uttrekking av B-61 veldig sensitivt i NATO. Amerikanske taktiske atomvåpen i Europa er definert som vitale for organisasjonen $\mathrm{i}$ NATOs offisielle dokumenter.

\section{NATOs offisielle politikk}

Mange av NATOs offisielle dokumenter beskriver kjernevåpen som en essensiell komponent i organisasjonen. Disse bidrar til utvidet avskrekking og byrdefordeling, og er dermed en nøkkelpilar for de transatlantiske bånd.

Selv om NATOs grunnleggende statutter, Atlanterhavspakten fra 1949, ikke nevner kjernevåpen, har NATOs strategiske konsept siden 1957 gjort den nukleære dimensjonen i Alliansen eksplisitt. Dagens strategiske konsept, vedtatt i 2010, beskriver NATO som en kjernevåpenallianse og fastsetter at NATO vil være avhengig av en kombinasjon av kjernefysiske og konvensjonelle evner så lenge det finnes atomvåpen i verden (NATO Strategic Concept 2010). Konsepter som "samhold", «solidaritet» og «byrdefordeling» er presentert som kjerneverdier og essensielle virkemidler for å opprettholde sterke atlantiske bånd. Kjernefysisk avskrekkelse er betegnet som et kjerneelement i NATOs strategi (NATO Strategic Concept 2010: 』17).

NATO er historisk grunnlagt i opposisjon til Sovjetunionen og ytterligere kutt av taktiske kjernevåpen er bare tenkelig dersom disse skjer i resiprositet med Russland. Det er anslått at Russland har mellom 3700 og 5400 taktiske kjernevåpen (Norris og Kristensen 2011: 67-74). Om lag 2400 av disse antas å være deployert og operasjonelle. Russlands langt større lagre av taktiske kjernevåpen er nok et kjerneargument for å beholde amerikanske B-61 i Europa. Samtidig ble mesteparten av de amerikanske kjernevåpnene i Europa trukket tilbake ensidig.

NATOs strategiskt konsept fra 2010 og Deterrence and Defence Posture Review (DDPR) fra 2012 giør ytterligere reduksjon avhengig av russisk resiprositet. Flere av intervjuobjektene i denne studien mener at B-61 blir beholdt fordi de kan være et forhandlingskort i fremtidige nedrustningsforhandlinger med Russland, ikke fordi de har en klar militær verdi. ${ }^{4}$ Dog synes dagens utsikter for forhandlinger dårlige.

${ }^{4}$ Intervju med to ansatte ved NATO-sekretariatet, Nuclear Policy Directorate, 26.11.2014, NATOs hovedkvarter, Brussel, Belgia. 
For det første har Russland langt flere taktiske kjernevåpen enn USA, og for det andre har russiske beslutningstakere gjort det klart at de ikke vil forhandle før USA er ferdig med å trekke ut B-61 fra Europa. Russland mener at utgangspunktet for begge land ikke er det samme. Sannelig ble alle taktiske kjernevåpen som var utplassert $i$ tidligere sovjet-stater brakt tilbake til Russland i $1993 .{ }^{5}$ USA er per i dag den eneste atommakten som har stridshoder utplassert på andre staters territorium.

Nødvendigheten av russisk resiprositet er imidlertid sterkt forankret i NATOs dokumenter (NATO 2014), en virkelighetsoppfatning som har stor støtte blant NATOs personale. En tidligere ansatt i NATO-sekretariatet (International Staff) som ble intervjuet $\mathrm{i}$ forbindelse med denne studien, mener at det er russerne som blokkerer prosessen:

If we could get the Russians to agree to begin to talk about this, but they are not going to talk about anything now, as a result of Ukraine, all moves of transparency were off the table. We don't know what do to until we get a dialogue down with the Russians. And that's not going to happen soon. There will be no dialogue on tactical nuclear weapons. And if there is a dialogue on tactical nuclear weapons, those people who don't want to move are going to have it their way. In other words, the Alliance is stuck. No one is going to say ' $\mathrm{Oh}$, this is a good time to remove these things', that ain't going to happen. ${ }^{6}$

Hendelsene i Ukraina fra og med 2014 har bidratt til at representanter fra NATOland og NATO-sekretariatet ikke anser dette som tiden for å diskutere uttrekking av B-61 fra Europa. Det fremholdes at NATO må fremstå samlet og ikke vise uenigheter, da dette kan tolkes som et svakhetstegn av Russland. På den annen side vil det alltid være en god unnskyldning for ikke å diskutere uttrekking av kjernevåpen, det vil alltid være en ny krise eller en ny fiende. ${ }^{7}$

\section{Institusjonell predisposisjon}

Institusjonelle trekk ved NATOs nukleære strategi peker i retning av "status quo». Dette fordi en endring kan tolkes som å stille spørsmål ved NATOs identitet og raison d'être. Noen land ser ingen sammenheng mellom NATO-solidaritet og B-61 på europeisk jord. Land som USA, Frankrike og Storbritannia, derimot, mener enden på nukleær byrdefordeling vil undergrave Alliansen.

Så lenge amerikanske kjernevåpen i Europa oppfattes som nyttige for å opprettholde en sterk og sammenhengende allianse, vil det være vanskelig for NATOs medlemsland å bli enige om uttrekking av bombene.

\footnotetext{
${ }^{5}$ NATO og USA understreker derimot det faktum at to tredeler av Russlands taktiske atomvåpenarsenal er lagret i Kaliningrad og på Kolahalvøya, med stor nærhet til NATO-land (Owen et al. 2011).

${ }^{6}$ Intervju med Lunn, Simon, tidligere ansatt ved NATO-sekretariatet, 29.10.2014, Brussel, Belgia. ${ }^{7}$ Dette har blant annet blitt påpekt av professor Tom Sauer ved Universitet i Antwerpen, Belgia, som ble intervjuet i forbindelse med denne studien 29.09.2014 og 11.2.2015.
} 
Siden NATO er en konsensusbasert organisasjon, er det vanskelig å endre eller reversere kontroversielle politiske spørsmål. Som påpekt av den tidligere amerikanske diplomaten som ble intervjuet i forbindelse med denne studien, er nasjonale delegasjoner redde for å ta opp kontroversielle spørsmål. Dette bidrar til status quo.

Because things are the way they are and because there is no consensus for change, then they will stay the way they are. We call that 'inertia', but in fact it's ill-disguised terror of raising difficult issues around the North Atlantic Council table. ${ }^{8}$

Uttrekking av B-61 fra de fem vertslandene i Europa ville bety slutten på nukleær byrdefordeling. Ikke-kjernevåpenstater ville ikke lenger fysisk ta del i NATOs kjernevåpenstrategi og det ville være begrenset behov for en Nuclear Planning Group (NPG). NATOs ikke-kjernevåpenstater ville miste innflytelse på NATOs kjernevåpenstrategi. Flere i NATO-sekretariatet ville dessuten miste jobben, og disse byråkratene kommer dermed med stor sannsynlighet til å motsette seg initiativer i denne retning.

\section{USA og Obama-administrasjonen}

USA er det eneste landet som har kjernevåpen utplassert utenfor egne grenser. Mens USA finansierer produksjon, transport, personell, vedlikehold og lagring av B-61, bidrar vertslandene med fysisk lagringsplass, infrastruktur for amerikansk personell og ekstern perimetersikring. Vertskapet er også forventet å disponere fly med dual kapasitet som både kan operere med konvensjonelle våpen og kjernevåpen (såkalte Dual Capable Aircraft).

Kort tid etter at president Obama tok over erklærte han sine visjoner om en verden uten kjernevåpen. Barack Obama annonserte at USA både ville redusere det fysiske lageret av kjernevåpen, og rollen til slike våpen i USAs sikkerhetsstrategi. President Obama skal ha hatt håp om å trekke B-61-bombene ut fra Europa, og var klar for å giøre dette unilateralt:

I think that's what President Obama had in mind back around 2009 before he got beaten up on by his own Department of Defense and Department of Energy and basically overruled by his own cabinet. He very much intended to do something about B-61s and I think he was prepared to do it unilaterally but he did not have the political capital to make that work in his own administration - much less with Congress [...] He wasted a great deal of political energy on other issues if you ask me. If he planned on making nuclear disarmament a signature of his administration, then he took on too many other things at once-including the health care reform [...] It did not leave him with enough sort of political weight within Washington DC. ${ }^{9}$

President Obama utpekte Ivo Daalder til NATO-ambassadør. Daalder var en kjent forkjemper for å trekke ut B-61. Verken Daalder eller Obama klarte imidlertid å

\footnotetext{
${ }^{8}$ Intervju med tidligere amerikansk diplomat ved USAs delegasjon til NATO, 16.3.2015.

${ }^{9}$ Intervju med tidligere amerikansk diplomat ved USAs delegasjon til NATO, 16.3.2015.
} 
samle den nødvendige støtte for å få våpnene tilbake til USA. I USAs Nuclear Posture Review, som er en gjennomgang av landets kjernevåpenpolitikk, ble det slått fast at endringer i utplasseringen av B-61 «should only be taken after a thorough review within - and decision by - the Alliance» (Nuclear Posture Review Report 2010: xiii). Dette kan forklares ut ifra flere faktorer. Først og fremst ville ikke president Obama kjempe mot forsvarsdepartementet og energidepartementet, som i hovedsak ønsker å la bombene bli hvor de er. For det andre var Obama betenkt på å presse fram et initiativ for å trekke B-61 ut av Europa, fordi han var redd det kunne sette på spill ratifikasjonen av den nye START-avtalen i Senate ${ }^{10}$ (Sauer og van der Zwaan 2010: 81). For det tredje var det å insistere på konsensus blant de NATO-allierte en fin måte å skille seg ut fra Bush-administrasjonen, som ofte ble kritisert for sine unilaterale beslutninger.

\section{Problemets kjerne: det militær-industrielle kompleks}

I USA kontrollerer energidepartementet og forsvarsdepartementet landets kjernevåpenpolitikk. De er sentrale og tunge aktører i det president Dwight D. Eisenhower kalte det militær-industrielle kompleks, det vil si skjæringspunktet mellom interessene til statlige etater og forsvarsindustrien.

The stakeholders are actually the departments of Defense and Energy. They tend to have very, very close ties on Capital Hill with the Republican Party. That's their natural constituency. [...] It's a jobs issue, it's a continuing work down the road, and continuing approbation from Congress in future years' issues so yeah, very much money, power, and influence within the government and jobs. ${ }^{11}$

Flere analytikere har lenge hevdet at det er NATOs øst-europeiske medlemmer som står i veien for å fjerne B-61-bombene. Polen og de baltiske statene, hevdes det, ser en avskrekkingsverdi i fortsatt utplassering av våpnene. Polen og de baltiske landene ønsker riktig nok en sterk amerikansk garanti mot eventuell russisk aggresjon. De har dog ikke bedt spesifikt om en nukleær garanti og har heller aldri uttalt seg offisielt mot tilbaketrekking av de taktiske kjernevåpnene. ${ }^{12}$ Selv om noen av de østeuropeiske statene skulle være imot uttrekking, er ikke deres interesser avgjørende, et argument som støttes av den amerikanske diplomaten:

They are against [a withdrawal], but they are not important. They can be persuaded in about ten minutes if you pull out a big enough checkbook and offer them enough goodies. They don't have a fundamental problem with it as long as they feel loved

\footnotetext{
${ }^{10} \mathrm{Ny}$ START-avtalen er en juridisk bindende avtale for å redusere strategiske kjernefysiske stridshoder og strategiske leveringssystemer. Den ble undertegnet av USA og Russland i 2010.

${ }^{11}$ Intervju med tidligere amerikansk diplomat ved USAs delegasjon til NATO, 16.3.2015.

${ }^{12} \mathrm{Et}$ medlem av det polske forsvarsdepartementet hevdet under en uformell samtale at bruk av taktiske kjernevåpen fra Europa ville påføre Polen store ødeleggelser. Ifølge en studie gjennomført av PAX, er Estland, Latvia og Polen positive til uttrekking av B-61 (Snyder og Van der Zeijden 2011).
} 
enough by NATO. [...] You can buy off the Balts and the Poles in about a week if you really wanted to get the nuclear weapons out of Europe. ${ }^{13}$

Ifølge denne kilden drar ansatte i forsvarsdepartementet og energidepartementet, ofte sammen med representanter fra de nukleære laboratoriene, til Europa flere ganger i året for å forsikre seg om at B-61-bombene forblir der de skal være.

They consult about various issues but if there is any potential sign that certain allies are discussing changes to nuclear posture and nuclear policy [...] you can be sure that they will be raising those issues with the allies in their capitals in absolute secrecy. [...] They talk about the whole range of NATO military-political issues but when they do this you can be absolutely certain that B-61 is on the menu, if it comes up they have a very strong Party line: 'you know we can't take these out of Europe especially now the way the Russians are treating the Ukrainians, we can't afford to show signs of weakness', you can imagine the whole thing. ${ }^{14}$

Forsvarsdepartementet og Energidepartementet driver lobbyvirksomhet i Europa for å forsvare sine økonomiske interesser. Dette gjør de ved å referere til Russland som en trussel, samt vise til behov for solidaritet innad i Alliansen. For å sikre seg at B-61 forblir i Europa, opprettholder de aktivt en diskurs der kjernevåpen, inklusive B-61, er avgjørende for NATOs sikkerhet og levedyktighet. Selv om enkelte stemmer i USAs forsvarsetablissement hevder at B-61 ikke har noen militær verdi, ${ }^{15}$ identifiserer Forsvardepartementets offisielle dokumenter en rekke fordeler ved å beholde disse kjernevåpnene i Europa. I en rapport fra Forsvarsdepartementet understrekes det at

Even though their number is modest, US nuclear capabilities in Europe remain a pillar of NATO unity. The manner in which they are geographically deployed and politically employed provides several benefits: (1) the weapons couple US and NATO security, tangibly assuring our allies of the United States' commitment to their security; (2) by extension they serve as an anti-proliferation tool by obviating allies' need to develop and field their own nuclear arsenals; (3) each member of the Alliance receives the benefits of increased protection and deterrence, while the burden of surety and security responsibilities and military risks associated with nuclear weapons are shared by many; (4) spread out across a wide area, nuclear weapons in Europe are less vulnerable than if they were concentrated at a single location; and (5) NATO Dual-Capable Aircraft (DCA) contribute directly to the nuclear deterrent mission and increase the deterrent value of the weapons. They convey the will of multiple allied countries, creating real uncertainty for any country that might contemplate

\footnotetext{
${ }^{13}$ Intervju med tidligere amerikansk diplomat ved USAs delegasjon til NATO, 16.3.2015.

${ }^{14}$ Intervju med tidligere amerikansk diplomat ved USAs delegasjon til NATO, 16.3.2015.

${ }^{15}$ The US European Command (EUCOM), tidligere betraktet som en sterk forkjemper for atomvåpen i Europa, anerkjenner ikke lenger nytten av B-61-bombene som er plassert i Europa. En tidligere amerikansk senioroffiser konstaterer at ' $[w]$ e pay a king's ransom for those things and ... they have no military value' (Department of Defense 2008: 59). Rapporten viser også til at taktiske atomvåpen, ifølge EUCOM, ikke har noen merverdi i avskrekkingsøyemed utover den de strategiske atomfasilitetene i USA allerede leverer. Ifølge flere av intervjuobjektene for denne studien støtter også US Air Force uttrekning av B-61s fra Europa.
} 
seeking political or military advantage through the threat or use of weapons of mass destruction against the Alliance (Department of Defense 2008: 16).

Denne rapporten hevder at tilstedeværelsen av amerikanske taktiske våpen i Europa sørger for en «essensiell politisk og militær kobling» mellom de allierte på begge sider av Atlanteren. Våpnene kobler USA til NATO. De er derfor av høy viktighet og uttrekking ville svekke Alliansen. Videre:

Even though the number of [B-61] weapons is modest when compared to total in-
ventories-especially Russian inventories of tactical weapons-the presence of US
nuclear weapons in Europe remains a pillar of NATO unity. The deployment of nu-
clear weapons in Europe is not a service or regional combatant command issue-it
is an Alliance issue. As long as NATO members rely on US nuclear weapons for
deterrence-and as long as they maintain their own dual-capable aircraft as part of
that deterrence-no action should be taken to remove them without a thorough and
deliberate process of consultation (ibid).

Selv om utplassering av kjernevåpen i Europa på 50- og 60-tallet var basert på bilaterale avtaler mellom USA og det enkelte vertsland, promoterer nå det amerikanske forsvarsdepartementet at enhver beslutning om å trekke ut B-61 må baseres på konsensus blant alle Alliansens medlemmer. Mens Canada (1989), Hellas (2001) og Storbritannia (2008) fremforhandlet fjerning av amerikanske kjernevåpen fra sitt territorium bilateralt med USA, er denne muligheten nå lukket.

Ifølge Pentagon trenger europeerne en sikkerhetsgaranti, som amerikanerne generøst tilbyr. Den eneste betingelsen er at de europeiske allierte bidrar til å dekke kostnadene og risikoen knyttet til kjernevåpen. Under sin avskjedstale i Brussel i april 2011 kritiserte tidligere forsvarsminister Robert Gates åpent europeiske allierte for ikke å bidra tilstrekkelig til byrdefordeling:

In the past, I've worried openly about NATO turning into a two-tiered alliance: Between members who specialize in 'soft' humanitarian, development, peacekeeping, and talking tasks, and those conducting the 'hard' combat missions. Between those willing and able to pay the price and bear the burdens of alliance commitments, and those who enjoy the benefits of NATO membership - be they security guarantees or headquarters billets - but don't want to share the risks and the costs. This is no longer a hypothetical worry. We are there today. And it is unacceptable (Gates 2011).

Dette kan forklare at europeiske allierte er villige til fortsatt å være vertskap for B-61 for å unngå fokus på manglende bidrag til NATOs sikkerhetsbudsjett. Gates' tale kan tolkes dit hen at det ikke ville bli akseptert dersom et europeisk vertsland besluttet å ikke lenger være vertskap for B-61-bombene. Dette er fremstilt som det minste disse landene kan giøre i en situasjon der USA bærer de største kostnadene.

Det er derimot viktig å huske at det står betydelige (skjulte) økonomiske interesser på spill for amerikanerne: 
From the Departments of Defense and Energy you spread out to the national laboratories at Sandia, Livermore, Los Alamos and from there you spread out further to private industries. The labs need work to do. That's their mother's milk. They get paid to plan these things, they employ people to plan these things, so President Obama saying you can't design new nuclear weapons, much less bringing them into production, was a slap in the face of these people. ${ }^{16}$

I USAs Nuclear Posture Review fra 2010 ble det annonsert at Obama-administrasjonen ikke ville utvikle nye kjernevåpen. Modernisering av eksisterende våpen, inklusive B-61, fortsetter imidlertid. Mange av de som ble intervjuet i NATO-sekretariatet påpekte at B-61 av sikkerhetshensyn må fornyes fra tid til annen, og at så lenge våpnene er del av NATOs strategi, vil moderniseringsprosessen fortsette. Den pågående moderniseringsprosessen for B-61 vil derimot skape en presisjonsbombe med addisjonelle kapabiliteter (Norris og Kristensen 2014). B-61-bombene stasjonert i Europa vil gjennomgå et såkalt «Life Extension Program» i USA, som vil konvertere dem til en ny type bombe: B61-12. Den vil bli utstyrt med en ny målrettingsmekanisme som forbedrer våpenets nøyaktighet, samtidig som man kan justere den eksplosive kraften før lansering (Norris og Kristensen 2014: 83). B61-12 vil dermed bli den første nukleære bomben som bruker moderne presisjonsteknologi, som vil giøre mindre utilsiktet skade og utløse mindre radioaktivt nedfall (ibid). Like fullt vil den nye B61-12, som skal deployeres i Europa om et par år, fremdeles ha en justerbar eksplosjonsstyrke på inntil 50000 tonn TNT - som tilsvarer mer enn tre ganger bomben som ble sluppet over Hiroshima i 1945.

Sandia National Laboratories er ansvarlig for å utvikle B61-12. I samarbeid med Los Alamos National Laboratories og US Air Force har de arbeidet på prosjektet siden 2011. Det er estimert at det vil koste mellom åtte og ti milliarder USD ${ }^{17}$ å produsere 400-500 B61-12 bomber; de vil bli ferdigstilt i 2018 og være aktive frem til 2040 (NNSA 2013).

Oppgraderingen av B61-12 vil i betydelig grad øke kapabiliteten og nøyaktigheten av bombene og giøre de mer anvendbare. Kombinert med et femtegenerasjons kampfly som er vanskelige å oppdage og skyte ned, kan dette lede til sterke reaksjoner fra Russland. Mulighetene for nedrustningsforhandlinger for taktiske kjernevåpen vil med all sannsynlighet også forverres (Seay 2012: 8).

B61-12 vil bli utstyrt med en målrettingsmekanisme tilknyttet det amerikanske kampflyet Lockheed Martin F-35 Lightning II. Dette innebærer at kun denne flytypen vil være i stand til a "kommunisere» med bomben og tillate operasjonalisering av den nye forbedrede målrettingsteknologien (Kristensen 2014). F-35 er med andre ord det eneste flyet som vil klare å gjøre full bruk av B61-12 sin økte

\footnotetext{
${ }^{16}$ Intervju med tidligere amerikansk diplomat ved USAs delegasjon til NATO, 16.3.2015.

${ }^{17}$ Dette er kostnadene knyttet til bomben i seg selv. Kostnadene ved å integrere B61-12 på jagerfly er ikke inkludert.
} 
treffsikkerhet. Følgelig er det press på de europeiske vertslandene for å erstatte sine aldrende kampfly (F-16 og Tornado) med den nye F-35.

Siden disse kampflyene er modne for utskiftning i inneværende tiår, er timingen perfekt for å selge de nye F-35 til Europa.

Muligheten for å gjøre B-61 operasjonell for de fleste moderne kampfly ble også indikert av NATO-tjenestemenn i 2012 (Seay 2012: 6). Utenlandske flyselskaper vil dog sannsynligvis være motvillige til å dele detaljer om sin teknologi med de amerikanske selskapene, noe som antas nødvendig for å få lisens for nukleære oppdrag (Thränert 2009: 5).

Utviklingen og produksjonen av F-35 sysselsetter om lag 130000 mennesker i USA (Seay 2012: 5). Anslagsvis 1300 innenlandske leverandører fra 47 av landets 50 delstater er involvert. Det er videre anslått at utviklingen av F-35 vil gi et direkte bidrag på 380 milliarder dollar til USAs økonomi. USA har dermed sterke motiver for å holde B-61 i Europa og modernisere bombene for å kunne selge F-35 kampfly:

If you are able to sell this as part of a nuclear package to replace the dual-capable aircraft that allies already have, it means that you are sort of that much closer to guarantee sales of the F-35. If you do that, if the allies that are hosting those weapons buy F-35, then you can turn to other potential buyers. ${ }^{18}$

Fortsatt nukleær byrdefordeling vil dermed øke USAs muligheter å selge F-35 kampfly.

Det er ikke noen overraskelse at tre av fem europeiske vertsland for B-61 Nederland, Italia og Tyrkia - allerede har signert kontrakter med Lockheed Martin for å kjøpe F-35. Belgia har ikke fattet noen offisiell beslutning, men F-35 blir av mange ansett som favoritt. Det tyske flyvåpenet har imidlertid valgt europeiske Eurofighter, som ikke kan frakte kjernevåpen.

\section{Støttespillere: atommaktene Frankrike og Storbritannia}

Franske og britiske myndigheter tillegger atomvåpen stor verdi, og begge synes fast bestemt på å beholde en kjernefysisk komponent i sine respektive sikkerhetsstrategier. Myndighetene frykter at enhver tilbaketrekking av B-61s fra Europa vil øke presset på dem for å avvæpne.

I tillegg fryktes det at Russland vil ønske å inkludere franske og britiske nukleære arsenal i forhandlinger rundt taktiske kjernevåpen med NATO. Den russiske Generaloberst Verkhovtsev uttalte til Pravda (2007) at «[w]e are ready to talk to the USA, but let us have other countries involved in the process as well, Great Britain and France first and foremost». Russiske representanter uttalte videre i 2009 at en diskusjon med NATO om reduksjon av taktiske atomvåpen bør inkludere representanter fra Frankrike og Storbritannia (NTI 2009).

\footnotetext{
${ }^{18}$ Intervju med tidligere amerikansk diplomat ved USAs delegasjon til NATO, 15.3.2015.
} 
Frankrike

Fransk opposisjon har vært blant hovedhindrene mot full uttrekking av B-61 fra Europa. Frankrike var èn av hovedkreftene som gikk imot initiativet fra Belgia, Tyskland, Luxembourg, Nederland og Norge, om å sette taktiske kjernevåpen på NATOs dagsorden i 2010. I tillegg bidrar den franske regjeringen og det politiske etablissementet aktivt med å videreføre den diskursive oppfatning av NATO som en «kjernefysisk allianse». I regjeringens Livre Blanc om forsvaret (2013) beskrives kjernefysisk avskrekking som

the ultimate guarantee of the security, protection and independence of the Nation. It ensures, permanently, our independence of decision-making and our freedom of action within the framework of our international responsibilities, including in the event of any threat of blackmail that might be directed against us in the event of a crisis (Livre Blanc 2013: 73).

Kjernefysisk avskrekking fremstilles som legitimt og nyttig ettersom det beskytter Frankrikes og NATOs interesser fra ekstern aggresjon. Dette er stort sett ikke bestridt i politiske sirkler i Frankrike. Franske regjeringer, uavhengig av konstellasjon og innflytelsesrike tenketanker, har lenge støttet opp om denne sikkerhetsstrategien. Det ville ikke være i Frankrikes interesse at forskjellen mellom kjernevåpenstater og ikke-kjernevåpenstater blir for viktig innenfor NATO, da dette ville medføre økt fokus på Frankrikes kjernevåpenarsenal.

Både Storbritannia og Frankrike har kjernevåpen som kan avfyres fra undervannsbåter, men bare Frankrike har kjernevåpen som kan leveres med fly. Uttrekning av B-61 fra Europa ville føre til at Frankrike ble det eneste europeiske land med kjernevåpen som kan leveres fra fly. I det hypotetiske tilfellet med forhandlinger mellom NATO og Russland ville sistnevnte kunne anmode om at Frankrikes nukleære arsenal inkluderes. ${ }^{19} \AA ̊$ opprettholde status quo er dermed det beste alternativet for Frankrike.

Fra Frankrikes perspektiv kunne altså en uttrekking av USAs B-61 fra Europa føre til økt oppmerksomhet om Frankrikes egne kjernevåpen. Dersom naboland som Belgia, Tyskland og Nederland ble atomvåpenfrie, ville presset på Frankrike for nedrustning sannsynligvis øke. Dette ville særlig være tilfelle dersom NATO fattet en konsensusbeslutning om at B-61 skulle trekkes ut (Tertrais og Facon 2008: 63).

På den annen side kan man også tenke seg at en amerikansk unilateral uttrekking av B-61 vil styrke stillingen til det franske nukleære arsenalet innad i Alliansen. Ifølge Bruno Tertrais ${ }^{20}$ kunne NATO-medlemmer som Polen og de baltiske land til og med komme til å be Frankrike om kjernevåpenforsikringer. Til tross for at dette kunne

\footnotetext{
${ }^{19}$ Tertrais og Facon (2008) mener at den russiske delegasjonen prøvde på nettop dette under SALT II-forhandlingene.

${ }^{20}$ Intervju med Tertrais, Bruno, seniorforsker ved Fondation pour la recherche stratégique (FRS), 17.3.2015.
} 
øke Frankrike status som stormakt og bidragsyter for sikkerhet, synes den franske posisjonen å være at tiltak som truer status quo i NATOs kjernevåpenpolitikk, ikke er velkomne.

\section{Storbritannia}

Storbritannias identitet som stormakt har lenge blitt assosiert med besittelse av kjernevåpen. Viktige aktører mener at Storbritannias historie, makt og verdier gir landet et spesielt ansvar for å bevare internasjonal fred og stabilitet (Ritchie 2010: 469-470). Å inneha kjernevåpen ses på som en forutsetning for å kunne spille en slik rolle. I henhold til et white paper fra 2010 er nukleær avskrekking "the ultimate insurance policy in this age of uncertainty», og Storbritannia er nødt til beholde «a credible, continuous and effective minimum nuclear deterrent for as long as the global security situation makes that necessary» (White Paper 2010: 5).

I likhet med Frankrike, vil en uttrekning av B-61 fra Europa sannsynligvis øke presset mot Storbritannia for å ruste ned. Britiske beslutningstakere er følgelig negative til ideen om å trekke ut B-61-bombene. Et annet aspekt er det spesielle forholdet mellom Storbritannia og USA. Storbritannia ønsker ikke å giøre noe som kan sette deres nære forhold til USA i fare.

Selv om det er langt mer omfattende diskusjoner og synlig anti-atomvåpenaktivisme i Storbritannia enn i Frankrike, fremstiller sentralt plasserte departementer og tenketanker B-61 som et essensielt bånd mellom USA og Europa, og nukleær avskrekking som en legitim sikkerhetsstrategi. Under en debatt i Overhuset uttrykte Lord Howell of Guildford, statssekretær i Utenriksdepartementet for De konservative, regjeringens posisjon angående B-61:

First, the presence of US nuclear forces based in Europe provides an essential political and military link between the European and North American members of the Alliance. Secondly, the B-61 nuclear weapon forms an important element of those nuclear forces and the national US life-extension programme (LEP) for the ageing bombers, which incidentally is paid for entirely by the United States, will ensure that it continues to be a safe, secure and credible nuclear deterrent without nuclear testing. That is an important benefit, or condition, of the LEP. Thirdly, at the same time, the participation of non-nuclear countries demonstrates alliance solidarity, a commitment to maintaining collective security and the widespread sharing of burdens and risks. Most of your Lordships, and many outside, would agree that we need to encourage a burden of sharing as much as possible. Fourthly, as the review makes quite clear, future decisions must also take into account the far greater Russian stockpiles of short-range nuclear weapons stationed in the Euro-Atlantic area. It would not be right for NATO unilaterally to disarm, nor to disarm by default-in other words, by not modernising the essential equipment. Future steps must be taken in the context of reciprocal steps by Russia (House of Lords 2012).

Likheten i retorikken mellom USA og Storbritannia er slående. Statssekretæren uttrykker seg i samme vendinger som representanter fra det amerikanske forsvarsdepartementet og energidepartementet: B-61 sørger for transatlantiske bånd, kjernefysisk 


\section{Maïka Skjønsberg}

avskrekking er en sentral pilar i NATO, kjernefysisk byrdefordeling viser solidaritet mellom Alliansens medlemmer, og videre, reduksjoner må være avhengig av russisk resiprositet. I en tale i 2009 argumenterte daværende forsvarsminister John Hutton at

All Allies have the responsibility to share the burden and the risks that come with them. It is not right to take the benefit of the insurance cover on offer, if you aren't prepared to pay the premium that goes with it (Hutton 2009).

Hutton argumenterte også for at europeiske stater bør øke sine utgifter til forsvarsformål: "freeloading on the back of US military security is not an option» (ibid). Statssekretæren i det britiske utenriksdepartementet uttalte dessuten at siden den finansielle kostnaden av programmet for levetidsforlengelse for B-61 helt og holdent var betalt av USA, er fortsatt tillatelse til utplassering av bombene på sine territorier det minste vertslandene kan giøre (House of Lords 2012).

\section{Lydige vertsland}

Juridisk sett kunne vertslandene avslutte sine respektive bilaterale avtaler med USA. Retorikken fra myndighetene i Frankrike, Storbritannia og USA indikerer imidlertid at bare det å diskutere saken kan bli betraktet som om man setter spørsmålstegn ved NATO-solidaritet og byrdefordeling.

Det kreves betydelig mot av vertslandene å be om at stridshodene fjernes fra deres territorium. Den sentralt plasserte amerikanske eksdiplomaten mener likevel at dersom de skulle stå på sine krav, vil USA trekke tilbake våpnene.

There would be consequences threatened, but at what point could we actually afford to initiate any real consequences to our good friends and allies, the Germans? [...] There might be more pressures against what's perceived as a smaller and weaker government but the same thing holds: if they stand on their principles and refuse to back down, those weapons come out. ${ }^{21}$

Tyskland

Rett etter at koalisjonsregjeringen, satt sammen av Kristeligdemokratene (CDU/ CSU) og Liberaldemokratene (FDP), kom til makten i 2009, erklærte de at

We strongly support US President Obama's submitted suggestions for extensive new disarmament initiatives-including the aim of a nuclear-free world [...] In this connection as well as during the elaboration of a NATO Strategic Concept, we will commit ourselves in the Alliance as well as towards the American allies to the withdrawal of the remaining nuclear weapons from Germany (Koalitionsvertrag 2009: 121-122).

Tysklands nye utenriksminister Guido Westerwelle tok ivrig opp saken om mulig uttrekning av B-61 fra Tyskland. Den tyske regjeringens bestemte posisjon

${ }^{21}$ Intervju med tidligere amerikansk diplomat ved USAs delegasjon til NATO, 16.3.2015. 
fremprovoserte sterke reaksjoner fra B-61 tilhengerne, både offentlig og bak lukkede dører.

Som et eksempel på offentlig "pushback», produserte en gruppe amerikanske og britiske beslutningstakere en policyrapport der de argumenterte at det tyske ønsket om å fjerne B-61 fra Büchel-basen var et egoistisk forslag som underminerte NATO:

The problem with Germany piously stepping first in line to renounce nuclear weapons on its territory is that the country has not concurrently renounced nuclear deterrence. It wants to continue to enjoy the protection of America's nuclear umbrella, without sharing the burden of risk associated with stationing weapons in Germany. In other words, the country wants others to risk nuclear retaliation on its behalf (Miller et al. 2010: 1-2).

Tysklands ønske om å fjerne de siste B-61 fremprovoserte også reaksjoner bak lukkede dører:

Things get sort of horse-traded at NATO like every other parliamentary body on earth. And the countries that took the right line when it comes to B-61s get more goodies. The Germans for example found that talking out publicly about getting rid of the things was not good in terms of their ability to get goodies at NATO. ${ }^{22}$

Disse reaksjonene forklarer hvorfor den tyske regjeringens initiativ for å fjerne våpnene døde hen. Nåværende regjering har tonet ned retorikken betydelig. Beslutningen om ikke å kjøpe den amerikanske F-35 kan imidlertid lede til nedrustning uten å skape særlig støy. Tyskland har valgt å kjøpe sine delvis egenutviklede Eurofighter Typhoon ${ }^{23}$ for å erstatte dagens Tornado, og Eurofighter kan per nå ikke frakte kjernevåpen.

Spørsmålet som gjenstår er om tyske myndigheter vil gjøre Eurofighter kjernefysisk kapabel. Ifølge Meier (2006) informerte regjeringen i 2004 Bundestag om at den ikke hadde til hensikt å sertifisere Eurofighter til å kunne bære kjernevåpen. Selv om uttalelsene fra den tyske regjeringen er vage, synes det logisk at å gjøre Eurofighter kjernefysisk kapabel ikke er et foretrukket alternativ. Dersom dette skulle skje måtte utviklerne av Eurofighter gi amerikanske motparter tilgang til kommersiell sensitiv informasjon. Videre ville Tyskland sannsynligvis måtte bære alle kostnadene ved å utvikle og installere program og utstyr som er nødvendig for å frakte kjernevåpen. Dette kunne i tilfelle beløpe seg til så mye som 300 millioner euro (Chalmers and Lund 2010:23).

Med sin beslutning om ikke å kjøpe F-35, og ikke gjøre Eurofighter kjernefysisk kapabel, kan tyske myndigheter ha funnet en mulighet til å oppnå uttrekning av B-61-bomber uten en stormfull diskusjon med sine allierte.

\footnotetext{
${ }^{22}$ Intervju med tidligere amerikansk diplomat ved USAs delegasjon til NATO, 16.3.2015.

${ }^{23}$ Eurofighter Typhoon er et kampfly utviklet av Italia, Storbritannia, Spania og Tyskland.
} 
Belgia og Nederland

I motsetning til i Tyskland, har aldri myndighetene i Belgia og Nederland offentlig uttalt noe ønske om å fjerne B-61 fra sine territorier. Begge lands myndigheter har insistert på å holde informasjon om B-61 gradert - noe som vanskeliggiør debattene rundt dette i parlamentet og samfunnet. To tidligere statsministre i Nederland, Ruud Lubbers og Dries van Agt, har faktisk blitt tiltalt for å snakke om vertskapet for atomvåpen. Mens førstnevnte ble tiltalt for å ha uttalt på nederlandsk TV at han «aldri ville trodd at de dumme tingene [B-61] fremdeles skulle være der i 2013» (Dutchnews 2013), ble van Agt tiltalt for å si at «de er der fremdeles og det er galskap».

Selv om det er vanskelig å ha en opplyst debatt om konfidensielle tema, er velgerne klar over bombene og generelt negative til disse. En valgdagsmåling i 2010 viste at 87 prosent av Nederlands befolkning var imot utplassering av kjernevåpen på nederlandsk jord (Van der Zeijden 2013). Ifølge en meningsmåling utført av Universitetet i Antwerpen i 2014 var 61 prosent for å trekke kjernevåpnene ut fra Belgia (RBTF 2014). Kjernevåpen er dog ikke et viktig tema, verken i nederlandsk eller belgisk politikk. Mens flere ikke-statlige organisasjoner og fredsnettverk arbeider for å fjerne våpnene, er deres innflytelse begrenset. Det finnes dermed ikke tilstrekkelig høye insentiver på hjemmebane for å ta opp denne vanskelige kampen i NATO.

I 1999 hevdet Belgias daværende forsvarsminister, André Flahaut, at den beste strategien for Belgia var å ligge lavt: «Regjeringen ønsker en felles strategi med alle allierte. Vi ønsker ikke å agere på en måte som kan fremmedgiøre privilegerte partnere, da dette kan risikere å bidra til at Belgia får mindre innflytelse» (Chambre des Représentants de Belgique 1999, min oversettelse). Ideen om å sitte stille i båten forblir viktig i belgisk utenriks- og sikkerhetspolitikk.

I 2009 foreslo den belgiske senatoren Philippe Mahoux fra Sosialistpartiet (PS) å vedta en ny lov som forbød lagring av kjernevåpen i Belgia (Sénat de Belgique 2009). Ett av hans argumenter var at Belgia ikke respekterte artikkel $2 \mathrm{i}$ ikke-spredningsavtalen, som sier at ikke-kjernevåpenstater ikke skal få overført, eller direkte eller indirekte ha noen kontroll over, kjernevåpen. ${ }^{24}$ Senatorens forslag møtte kraftig motbør fra regjeringen. I en gradert e-post sendt fra Brussel til hhv. USAs utenriks- og forsvarssekretariat i juli 2009 beskrives senator Mahoux' lovforslag i svært negative termer, og USA forsikres om at lovforslaget ikke vil bli vedtatt (Wikileaks 2009a). Vincent Mertens de Wilmars, rådgiver til forsvarsminister Pieter de Crem, forsikret en amerikansk diplomat om at "the government will be ready to

\footnotetext{
${ }^{24}$ «Each non-nuclear-weapon State Party to the Treaty undertakes not to receive the transfer from any transferor whatsoever of nuclear weapons or other nuclear explosive devices or of control over such weapons or explosive devices directly, or indirectly [...]» (NPT 1968). Flere analytikere argumenterer for at USA fortsatt har kontroll over bombene, og at man dermed ikke kan si at traktaten er brutt. I tillegg hadde USA allerede utplassert kjernevåpen i Europa, da avtalen ble inngått - noe som kan tyde på at dette var akseptert av alle partnere som undertegnet avtalen.
} 
meet it [the law proposition] and will find ways to ensure it becomes bogged down in procedures and ultimately fails» (ibid). Senator Mahoux sitt forslag ble følgelig felt av prosedyremessige innsigelser. En lang liste av lovforslag og resolusjoner fremmet i parlamentet av den flamske sosialisten Dirk Van der Maelen (intervjuet i forbindelse med denne studien ${ }^{25}$ ) har møtt samme skjebne. Tilsvarende har skjedd i Nederland, der partier på venstresiden fremmet flere resolusjoner om uttrekning av B-61, men uten suksess. ${ }^{26}$

I henhold til en gradert e-post gjengitt av Wikileaks, ønsket den daværende belgiske utenriksminister Yves Leterme velkommen den tyske regjerings erklæring fra 2009 om å trekke ut amerikanske kjernevåpen fra Tyskland (Wikileaks 2009b). E-posten indikerer at hhv. Utenriks- og Forsvarsdepartementet i Belgia måtte tøyle minister Leterme, som hadde vært for positiv til en slik idé.

Tilsvarende har skjedd i Nederland. I 2012 berettet tidligere utenriksminister Timmermans (Arbeiderpartiet) parlamentet om sitt ønske om å få B-61 trukket ut:

As is commonly known, my party is in favour of giving up the nuclear task that the Netherlands still has in NATO. Therefore, there should be negotiations with the US about removing the nuclear weapons that possibly are on Dutch territory. These weapons have lost any military significance. For a political role they don't have to be on Dutch territory. My party wants these weapons removed, if necessary in a bilateral context (Van der Zeijden 2012: 1).

Utenriksminister Timmermans' uttalelse ble imidlertid aldri gjentatt eller fulgt opp. I et brev til parlamentet angående regjeringens holdning til nedrustning og ikke-spredning noen få måneder senere, hadde tonen endret seg betraktelig (Timmermans 2013). I brevet hevdes det at USA og Nederland er enige om at videre tiltak angående taktiske kjernevåpen vil avhenge av fremgang i forhandlingene med Russland, så vel som enighet innen NATO (ibid). Nederland vil ikke handle unilateralt.

I Nederland tok diskusjonen om erstatning av F-16 tolv år. Beslutningen om F-35 var ikke noen overraskelse, særlig da Nederland siden 2011 har investert USD 800 millioner i utviklingsprogrammet. I november 2012 ratifiserte det nederlandske parlamentet regjeringens valg om å erstatte F-16 med F-35A. I mars 2015 bestilte forsvarsdepartementet de første åtte flyene. Planen er å anskaffe 37 amerikanske kampfly for en samlet sum på 4,5 milliarder euro (RBTF 2015). Selv om det ikke er formelt besluttet hvorvidt de bestilte F-35A skal ha nukleær kapabilitet, antar flere eksperter at den nukleære opsjonen vil beholdes.

\footnotetext{
${ }^{25}$ Intervju med Van der Maelen, Dirk, belgisk parlamentariker, representant for Socialistische Partij Anders, leder av kommisjonen for eksterne relasjoner, 1.4.2015, Brussel, Belgia.

${ }^{26}$ I både Belgia og Nederland er høyreorienterte politiske partier mer pro-atlantiske enn venstreorienterte partier. Grønne og sosialdemokratiske partier er på generell basis tilhengere av å trekke ut våpnene.
} 
Belgia har investert $\mathrm{i}$ et livsforlengende program for sine F-16 slik at de kan forbli operative til omkring 2020. Hvilken flytype som vil erstatte F-16 er ennå ikke besluttet. Tre fly er fortsett med i konkurransen: F-35, franske Rafale og Eurofighter. Lockheed Martins F-35 er klar favoritt. I et intervju for denne studien fremholdt den belgiske parlamentarikeren Van der Maelen at «we feel there are huge pressures from the US to acquire the F-35».

I et lekket dokument fra det belgiske forsvarsdepartementet fremgår det at det belgiske militæret ønsker at etterfølgeren til F-16 skal være kjernevåpen-kapabel, det vil si at den skal kunne frakte kjernevåpen (Defensie Plan 2015). Det lekkede dokumentet understreker også at F-16, pga. sin duale kapasitet (hhv. konvensjonell og kjernevåpen), tillater Belgia å spille en ledende rolle innen NATO (Defensie Plan 2015: 111). I mars 2015 underskrev Belgia og Nederland en avtale om felles overvåking av luftrommet i Benelux. Dette øker presset på Belgia for å velge F-35 ytterligere, da det kan hevdes å være en fordel at de to landene bruker samme type fly. Eksempelvis fortalte en nederlandsk general til belgiske parlamentarikere at forskjellig utstyr i de to landene ville svekke effektiviteten av samarbeidet (La Libre 2015b). Belgia har imidlertid et begrenset forsvarsbudsjett, og F-35 er det dyreste alternativet. Det er anslått at det vil koste mellom fire og seks milliarder euro å kjøpe et førtitalls F-35 (La Libre 2015a).

\section{Konklusjon}

Flere mektige aktører sørger for fortsatt utplassering av cirka 180 amerikanske atombomber av typen B-61, fordelt på fem ulike europeiske land. Det amerikanske militærindustrielle kompleks skaper og opprettholder, på grunn av sine sterke økonomiske interesser, en retorikk der de utplasserte bombene er nødvendige for Alliansens samhold. Frankrike og Storbritannia har sine egne nasjonale interesser på spill og bidrar til retorikken om at kjernefysisk avskrekking er legitimt, og at byrdefordeling er et moralsk ansvar for NATO-allierte. Vertslandene på sin side er motvillige til å presse på for en endring av status quo. De politiske gevinstene ved å trekke tilbake våpnene er høyst minimale $\mathrm{i}$ forhold til de forventede reaksjoner fra Alliansens seniorpartnere.

Det finnes flere alternativer for å fjerne bombene fra Europa. For det første kan USA og Russland redusere og eliminere sine taktiske kjernevåpen gjennom en bilateral avtale. Da Russland mener at alle B-61s må fjernes fra europeisk territorium før diskusjoner kan finne sted, virker imidlertid fruktbare forhandlinger usannsynlig. En tilbaketrekking kunne også skje gjennom en mer omfattende avtale mellom NATO og Russland, men Storbritannia og særlig Frankrike motsetter seg å inkludere sine kjernevåpenarsenaler i slike forhandlinger. Videre peker ikke dagens forhold mellom NATO og Russland mot snarlige nedrustningsinitiativer. Tilbaketrekking av våpnene $\mathrm{i}$ sammenheng med nedrustningsforhandlinger med Russland er like fullt det eneste alternativet de 28 NATO landene har sagt seg enige i. 
En annen mulighet er en konsensusbeslutning i Alliansen om å fjerne B-61bombene fra Europa. Da kjernevåpenstatene er sterkt imot en slik løsning, virker dette utfallet imidlertid svært usannsynlig.

En siste mulighet er at vertslandene starter bilaterale forhandlinger med USA for å fjerne bombene fra sitt territorium. Dette er kanskje det alternativet som har størst mulighet for å lykkes, til tross for at det gjenstår store hindringer. Mektige aktører mener slike tiltak står i sterk motsetning til sentrale NATO-verdier som «byrdefordeling» og «alliansesolidaritet». Så lenge vertslandene ligger langt under målet om å bruke to prosent av bruttonasjonalproduktet til forsvar, ${ }^{27}$ vil forespørsler om å fjerne bombene bli negativt mottatt. På den annen side kan større bevissthet og engasjement fra befolkningen om å fjerne atombomber fra sitt territorium, hjelpe vertslandenes myndighet til å stå på sine krav ovenfor USA.

Uttrekking av våpnene fra europeisk territorium vil ikke nødvendigvis innebære nedrustning; tilbaketrekking kan enkelt bety relokalisering av bombene til USA. Muligheten for å holde de europeiske lagringsanleggene klar for ny utplassering har blitt diskutert i NATO. Imidlertid har dette alternativet i stor grad blitt forkastet ettersom enhver ny utplassering trolig ville eskalere spenninger med Russland. Et annet alternativ som har vært diskutert er å fjerne bombene fra Belgia, Tyskland og Nederland, men beholde de som er i Italia og Tyrkia. Den tidligere amerikanske diplomaten som ble intervjuet for denne studien erklærte at flytting av alle B-61-bombene til Aviano-basen i Italia er diskutert innad i Alliansen.

For i det hele tatt å tillate uttrekking av B-61 fra Europa, må den dominerende diskursen endre seg. En vesentlig endring i retorikken fra Washington DC kan potensielt være nok til å forårsake en slik endring. Dette er imidlertid ikke noe USA kommer til å gjøre frivillig. Selv om det kan tenkes at president Trump ikke lenger ønsker å bidra like mye til NATO og beskytte sine europeiske allierte med kjernevåpen som ikke har militær nytte og som koster en formue, er det lite sannsynlig at han vil endre retorikken når han hører hvor mye penger og arbeidsplasser USA får igjen for å selge sine F-35 som del av byrdefordelingspakken. Derimot er hele retorikken rundt kjernevåpen i vesentlig endring - noe som kommer til å legge større nedrustningspress på kjernevåpenmaktene. Siden 2010 har den diplomatiske innsatsen for et atomvåpenforbud blitt trappet opp (Kmentt 2016). I oktober 2016 ble det vedtatt i FN å starte internasjonale forhandlinger for å forby kjernevåpen. Atomvåpenforbudet ble vedtatt i juli 2017 med 122 stemmer. Gjennom det såkalte «humanitære initiativet» har man tatt sikte på å delegitimere atomvåpen ved å referere til de humanitære konsekvensene ved bruk av denne typen masseødeleggelsesvåpen. Ved å utfordre den dominerende fortellingen om at kjernevåpen er legitime og nyttige, kan slike tiltak - over tid - utfordre status quo.

${ }^{27}$ I 2016 brukte Belgia 0,9\%, Nederland 1,14\% og Tyskland 1,2 \% av sitt bruttonasjonalprodukt på forsvar. 


\section{Maïka Skjønsberg}

\section{Om artikkelen:}

Artikkelen er basert på forfatterens masteroppgave i Internasjonale relasjoner ved Université Libre de Bruxelles (ULB). Den tar utgangspunkt i en analyse av offisielle dokumenter på engelsk, tysk og fransk samt tretten intervjuer gjennomført med NATO-ansatte, politikere og tidligere diplomater.

\section{Litteratur}

Chambre des Représentants de Belgique (1999), Bulletin n B015 - Question et réponse écrite $\mathrm{n}^{\circ} 0035$ législature 50, http://www.lachambre.be/kvvcr/showpage. $\mathrm{cfm}$ ? section=qrva\&language $=\mathrm{fr} \& \mathrm{cfm}=\mathrm{qrvaXml}$. cfm?legislat=50\&dossierID=50-b015-16-0035-1999200000423.xml

Defensie Plan (2015), De Belgische Defensie van de toekomst: Horizon 2030, 6. mars 2015, https://twitter.com/ JensFranssen/status/582792110304268288

Department of Defense (2008), Report of the Secretary of Defense Task Force on DoD Nuclear Weapons Management, Phase II: Review of the DoD Nuclear Mission (2008), U.S. DoD, http://www.defense.gov/pubs/pdfs/ phaseiireportfinal.pdf

Ducthnews (2013), «22 American nuclear bombs are stored in the Netherlands: media», DutchNews.nl, 10 juni 2013, http://www.dutchnews.nl/news/archives/2013/06/22_american_nuclear_bombs_are/

Gates, M. Robert (2011), "The Security and Defense Agenda (Future of NATO)», Secretary of Defense Robert M. Gates, Speech, Brussels, Belgium, 10. juni 2011, http://www.defense.gov/speeches/speech.aspx?speechid=1581

Gregory, Shaun R. (1996), Nuclear Command and Control in NATO - NuclearWeapons Operations and the Strategy of Flexible Response, New York, MacMillan Press LTD.

House Of Lords (2012), House of Lords debates NATO's Deterrence and Defence Posture Review, 29. mai 2012, http://toplevelgroup.org/in-parliament/debates/debates-in-2012/house-of-lords-debates-natos-deterrenceand-defence-posture-review/

Hutton, John (2009), "NATO at 60: Towards a New Strategic Concept», Speech delivered by the UK Secretary of State for Defence at Wilton Park, 15 januar 2009, http://www.acronym.org.uk/proliferation-challenges/ natonuclear-allies/nato-60-towards-new-strategic-concept?page $=5$

Kmentt, Alexander (2016), "The development of the international initiative on the humanitarian impact of nuclear weapons and its effect on the nuclear weapons debate", International Review of the Red Cross, vol. 897, juli 2016.

Koalitionsvertrag (2009), Wachstum. Bildung. Zusammenhalt, Koalitionsvertrag zwischen CDU, CSU und FDP, 26. oktober 2009, http:/www.csu.de/politik/beschluesse/koalitionsvertrag-zwischen-csu-csu-und-fdp/

Kristensen, Hans (2014), "General Confirms Enhanced Targeting Capabilities of B61-12 Nuclear Bomb», FAS, 23. januar 2014.

La Libre (2015a), "On nous pousse dans les bras du F-35», 22. januar 2015, http://www.lalibre.be/actu/belgique/ on-nous-pousse-dans-les-bras-du-f-35-54bfe7503570af82d4ff9e4e

La Libre (2015b), «Le parlement néerlandais s'inquiète des économies touchant l'armée belge», 11. februar 2015, http:/www.lalibre.be/actu/belgique/le-parlement-neerlandais-s-inquiete-des-economies-touchant1-armee-belge-54db5c4b35701001a1ab724c

Letter to Secretary General (2010), Letter to the Secretary General by the Ministers of Foreign Affairs of Belgium, Germany, Luxembourg, the Netherlands and Norway, 26 februar 2010, https:/www.armscontrol.org/system/ files/Letter\%20to\%20Secretary\%20General\%20NATO.pdf.

Lie, Fredrik (2014), «Saying no to nukes», International Law and Policy Institute, Background Paper, no. 10, 2014, http://nwp.ilpi.org/wp-content/uploads/2014/09/BP10_2014_Saying-no-to-Nukes-WEB.pdf.

Livre Blanc (2013), Le Livre Blanc sur la Défense et la Sécurité Nationale, Ministère de la Défense, Paris, mai 2013.

Meier, Oliver (2006), "News Analysis: An End to US Tactical Nuclear Weapons in Europe?», Arms Control Today, 1. juli 2006, http://www.armscontrol.org/act/2006_07-08/NewsAnalysis

Miller et al. (2010), 'Germany opens Pandora's box', Center for European Reform, Briefing note, februar 2010, s. $1-2$.

Nato (2014), "NATO and Russia - Time to engage», Remarks by NATO Secretary General Anders Fogh Rasmussen at the Munich Security Conference, februar 2014, http://www.nato.int/cps/en/natolive/opinions_106788.htm

Nato non-Paper (2011), Non-paper submitted by Poland, Norway, Germany and the Netherlands on increasing transparency and confidence with regard to tactical nuclear weapons in Europe, 14. april 2011, http://fas.org/blogs/ security/2011/04/natoproposal/ 


\section{Nato og amerikanske kjernevåpen i Europa}

Nato Parliamentary Assembly Report (2010), U.S. non-strategic nuclear weapons in Europe: a fundamental NATO debate, Knops Raymond (rapporteur), 212 DSCFC 10 E rev 1, http:/www.nato-pa.int/default. asp?SHORTCUT $=2083$

Nato Strategic Concept (2010), Active Engagement, Modern Defense-Strategic Concept for the Defense and Security of the Members of the North Atlantic Treaty Organization adopted by Heads of State and Government in Lisbon 19.-20. november 2010, NATO Public Diplomacy Division, Belgium.

NNSA (2013), "Congressional Testimony», National Nuclear Security Administration, 30. oktober 2013, http:// nnsa.energy.gov/mediaroom/congressionaltestimony/lep

Norris, Robert S., og Kristensen, Hans (2011), "US tactical nuclear weapons in Europe, 2011», Bulletin of the Atomic Scientists 67(1), s. 64-73.

NPT (1968), The Treaty on the Non-Proliferation of Nuclear Weapons, www.un.org/en/conf/npt/2005/npttreaty.html

NTI (2009), «US, Russia Could Discuss Nonstrategic Nuke Cutbacks After START Talks», NTI, 7. mai 2009, http:/www.nti.org/gsn/article/us-russia-could-discuss-nonstrategic-nuke-cutbacks-after-start-talks/

Nuclear Posture Review (2010), Nuclear Posture Review Report, U.S. Department of Defense, april 2010.

Obama, Barack (2009), Remarks by President Barack Obama, Prague, Czech Republic, 5. april 2009, https:// www.whitehouse.gov/the_press_office/Remarks-By-President-Barack-Obama-In-Prague-As-Delivered/

Owen, David et al. (2011), "NATO Must Lead on Nuclear Disarmament", European Leadership Network (ELN), 16. februar 2011, http://www.europeanleadershipnetwork.org/nato-must-lead-on-nuclear-disarmament_62.html

Pomper, M., Potter, W., og Sokov, N. (2010), "Reducing tactical nuclear weapons in Europe», Survival 52(1), s. 75-96.

Pravda (2007) «Russia determined to keep tactical nuclear arms for potential aggressors» translated from Russian by Dmitry Sudakov, 31.oktober 2007, http://english.pravda.ru/russia/kremlin/31-10-2007/99911-nuclear_arms-0/

Ritchie, Nick (2010), "Relinquishing nuclear weapons: identities, networks and the British bomb», International Affairs 86(2), s. 465-487.

Rtbf (2014), «Six Belges sur dix souhaitent le retrait des armes nucléaires de Belgique», 26. september 2014, http://www.rtbf.be/info/belgique/detail_six-belges-sur-dix-souhaitent-le-retrait-des-armes-nucleaires-de-belgique? $\mathrm{id}=8364429$

Rtbf (2015), «Les Pays-Bas ont acheté leurs huit premiers chasseurs F-35», 26. mars 2015, http://www.rtbf.be/ info/monde/detail_les-pays-bas-ont-achete-leurs-huit-premiers-chasseurs-f-35?id=8941454

Sauer, Tom, og Van der Zwaan, Bob (2012), «U.S. tactical nuclear weapons in Europe after NATO’s Lisbon Summit: Why their withdrawal is desirable and feasible", International Relations 26, s. 78-100.

Seay, Edmond E. (2012), "Escalation by Default: The Future of NATO Nuclear Weapons in Europe», NATO Policy Brief n ${ }^{\circ} 2$, European Leadership Network.

Seay, Edmond E. (2013), "NATO’s Nuclear Guardians: Why NATO's bureaucracy is unable to initiate change to, or support reform of, Alliance nuclear policy", Nuclear Policy Paper n¹3, ACA, BASIC and IFSH.

Sénat de Belgique (2009), Proposition de loi complétant la loi du 8 juin 2006 réglant des activités économiques et individuelles avec des armes, en ce qui concerne l'interdiction des armements nucléaires déposée par M. Philippe Mahoux, Document législatif $\mathrm{n}^{\circ} 4-1441 / 1$, 7. oktober 2009, http:/www.senate.be/www/?MIval=/publications/ viewPub\&COLL=S\&LEG=4\&NR=1441\&PUID=67111187\&LANG=fr

Snyder, Susi, og Van Der Zeijden, Wilbert (2011), "Withdrawal Issues - What NATO countries say about the future of tactical nuclear weapons in Europe", IKV Pax Christi, mars 2011.

Tertrais, Bruno, og Facon, Isabelle (2008), «Les armes nucléaires “tactiques” et la sécurité de l'Europe», Paris, Fondation pour la recherche stratégique (FRS), januar 2008.

Thränert, Oliver (2009), «NATO, Missile Defense and Extended Deterrence», Survival: Global Politics and Strategy 51(6), s. 63-76.

Timmermans, Frans (2013), Beleidsbrief nucleaire ontwapening en non-proliferatie, 24. oktober 2013, English translation provided by the Ministry of Foreign Affairs: http://nonukes.nl/dutch-policy-letter-on-nuclear-weapons/

Van Der Zeijden, Wilbert (2013), "A new twist in the nuclear sharing omerta", 10. september 2013, NATO WATCH, http://www.natowatch.org/node/1214

Warner, Geoffrey (1989), "The Anglo-American special relationship», Diplomatic History, vol. 13, no. 4, 1989.

White Paper (2010), Securing Britain in an Age of Uncertainty: The Strategic Defence and Security Review, oktober 2010, https://www.gov.uk/government/uploads/system/uploads/attachment_data/file/62482/strategic-defence-security-review.pdf

Wikileaks (2009a), "Belgian MP to propose law banning nuclear weapons from Belgian soil», 30. juli 2009, https://www.wikileaks.org/plusd/cables/09BRUSSELS1044_a.html

Wikileaks (2009b), «Scenesetter for bilateral meetings with Belgian leaders during the secretary's December 3-4 visit to Brussels", 24. november 2009, https://wikileaks.org/plusd/cables/09BRUSSELS1580_a.html 


\begin{abstract}
English
The total number of US nuclear weapons in Europe has decreased by 97 per cent since its peak in the 1970s. Despite a series of political initiatives to have the remaining warheads withdrawn, approximately 180 US B-61 nuclear weapons remain on European soil: in Belgium, Germany, the Netherlands, Italy, and Turkey. Yet, the Cold War has been over for over two decades and those tactical, short-range nuclear weapons do not seem to serve a military purpose. NATO's nuclear capacity would not be altered by their withdrawal from European territory. So, the question is: why are those nuclear weapons still there?

This article identifies a set of actors that, by actively perpetuating a discourse casting NATO as a 'nuclear alliance' founded on 'burden sharing' and 'transatlantic solidarity', ensure the continuation of the stationing of US nuclear weapons in Europe.
\end{abstract}

Keywords: NATO • nuclear burden-sharing • tactical nuclear weapons • transatlantic solidarity · US military-industrial complex • B-61; F-35 